\section{Antiacetylcholinesterase and antioxidant activity of essential oils from six medicinal plants from Burkina Faso}

\author{
Martin Kiendrebeogo, ${ }^{*}, 1$ Ahmed Y. Coulibaly, ${ }^{1}$ Roger C. H. Nebie, ${ }^{2}$ \\ Boukaré Zeba, ${ }^{1}$ Charles E. Lamien, ${ }^{1,3}$ Aline Lamien-Meda, ${ }^{1}$ Odile \\ G. Nacoulma ${ }^{1}$
}

${ }^{1}$ Laboratoire de Biochimie \& Chimie Appliquées, UFR/SVT, Université de Ouagadougou, Burkina Faso,

${ }^{2}$ Département Substances Naturelles, Institut de Recherches en Sciences Appliquées et Technologies, Burkina Faso,

${ }^{3}$ FAO/IAEA Agriculture and Biotechnology Laboratory, Animal Production Unit, International Atomic Energy Agency, Austria.
Revista Brasileira de Farmacognosia Brazilian Journal of Pharmacognosy 21(1): 63-69, Jan./Feb. 2011

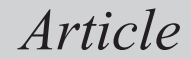

Received 6 Dec 2009

Accepted 7 Jul 2010 Available online 24 Jan 2011

Keywords: acetylcholinesterase inhibition mechanism antioxidant activity Eucalyptus camaldulensis Ocimum canum Ocimum basilicum

ISSN 0102-695X doi: 10.1590/S0102-695X2011005000008

\section{Introduction}

Acetylcholinesterase (AChE, EC. 3.1.1.7) is a key enzyme catalysing the hydrolysis of acetylcholine $(\mathrm{ACh})$ in the nervous system of animals and insects. ACh deficiency in the cerebral cortex of humans is one of the major futures seen in sufferers of Alzheimer's disease (Bierer et al., 1995). Recent studies have pointed out that $ß$-amyloid peptides found in Alzheimer's disease brain can induce inflammatory process with subsequent liberation of radical oxygen species (Vina et al., 2004; Stuchbury \& Munch, 2005) acting as secondary messenger in inflammation. A promising approache for treating Alzheimer's disease is to boost the level of ACh in the brain using AChE inhibitors (Enz et al., 1993). Antioxidants may contribute to this chemotherapy by attenuating inflammation pathways (Gibson \& Huang, 2005) through their ability to scavenge free radicals.

Recently, interest has increased in natural substance that could be supplied as food components or specific pharmaceutics for human well being. Among those, essential oils from aromatic and medicinal plants has been known to exhibit antioxidant and antiacetylcholinesterase properties (Perry et al., 2003;
Politeo et al., 2007; Sacchetti et al., 2005; Savelev et al., 2003). Cymbopogon citratus, Cymbopogon giganteus, Eucalyptus camaldulensis, Lippia multiflora, Ocimum canum and Ocimum basilicum are very common in Burkina Faso. Their essential oils are traditionally used in aromatherapy and as insects repellent or insecticide (Nacoulma, 1996).

This paper deals with the antiacetylcholinesterase and antioxidant activity of those six essential oils. The chemotype and inhibitory mechanisms on eel AChE of the most promising essential oils were reported.

\section{Materials and Methods}

\section{General procedures}

Acetylthiocholine iodide (ATCI), 5,5'-dithiobis [2-nitrobenzoic acid] (DTNB), acetylcholinesterase (AChE) type VI-S from electric eel, tris [hydroxymethane], bovine serum albumin (BSA), magnesium chloride hexahydrate, galanthamine hydrobromide and gallic acid were supplied from Sigma (USA). Trichloroacetic acid and 2,2-dipheny- 
1-1-picrilhydrazyl (DPPH) were provided from Fluka Chemika (Switzerland). Potassium hexacyanoferrate $\left[\left(\mathrm{K}_{3} \mathrm{Fe}(\mathrm{CN})_{6}\right]\right.$ and ascorbic acid were purchased from Labosi (France). Bioassays were performed on a double beam spectrophotometer (Uvikon 923, BioTek Kontron instruments). Composition of essential oils were achieved on a Hewlett-Packard 5890 gas chromatograph coupled with a Hewlett-Packard 5972 mass selective detector.

\section{Plant materials and essential oils extraction}

Fresh leaves of Cymbopogon citratus DC, Cymbopogon giganteus Chiov, Eucalyptus camaldulensis Dehnhardt, Lippia multiflora Moldenke, Ocimum canum Sims and Ocimum basilicum L. were collected at Gampela (25 km, east of Ouagadougou; Burkina Faso). Collection and taxonomic identification were carried out by Dr Amadé Ouedraogo, botanist from the Laboratoire de Biologie et d'Ecologie Vegetales (University of Ouagadougou, Burkina Faso).

Fresh leaves were subjected to hydrodistillation for $3 \mathrm{~h}$ using a Clevenger-type apparatus. The obtained essential oils were dried over anhydrous sodium sulphate and stored in dark glass bottle at $4{ }^{\circ} \mathrm{C}$ until use.

\section{Antiacetylcholinesterase activity}

The inhibitory effect of essential oils on acetylcholinesterase activity was evaluated using and adaptation of the spectrophotometric method of Ellman et al. (1961). Briefly, $100 \mu \mathrm{L}$ of essential oil $(0.1 \%$ in $50 \mathrm{mM}$ Tris- $\mathrm{HCl}, \mathrm{pH} 8$ buffer, $10 \%$ methanol) was mixed with $100 \mu \mathrm{L}$ of $\mathrm{AChE}(0.22$ $\mathrm{U} / \mathrm{mL}$ in $50 \mathrm{mM}$ Tris-HCl, $\mathrm{pH} 8$ buffer, $0.1 \%$ BSA) and $200 \mu \mathrm{L}$ of buffer $(50 \mathrm{mM}$ Tris- $\mathrm{HCl}, \mathrm{pH} 8,0.1 \%$ BSA). Mixture was incubated for $5 \mathrm{~min}$ at $30^{\circ} \mathrm{C}$ in a $1 \mathrm{~mL}$ cuvette. Subsequently, $500 \mu \mathrm{L}$ of DTNB (3 $\mathrm{mM}$ in Tris- $\mathrm{HCl}, \mathrm{pH} 8$ buffer, $0.1 \mathrm{M} \mathrm{NaCl}, 0.02 \mathrm{M}$ $\mathrm{MgCl}_{2}$ ) and $100 \mu \mathrm{L}$ of ATCI ( $4 \mathrm{mM}$ in water) were added. A blank was also prepared by replacing AChE with $100 \mu \mathrm{L}$ of buffer $(50 \mathrm{mM}$ Tris-HCl, $\mathrm{pH} 8$ buffer, $0.1 \% \mathrm{BSA}$ ). The reaction was monitored for $5 \mathrm{~min}$ at $412 \mathrm{~nm}$ and initial velocity $\left(\mathrm{V}_{0}\right)$ recorded. Buffer $(0.1 \%$ in $50 \mathrm{mM}$ Tris- $\mathrm{HCl}, \mathrm{pH} 8,10 \%$ methanol) was used as negative control. Antiacetylcholinesterase activity (I \%) was calculated as following:

$$
\mathrm{I}(\%)=\left(1-\mathrm{V}_{0 \text { Sample }} / \mathrm{V}_{0 \text { Blank }}\right) \times 100
$$

$\mathrm{V}_{0 \text { Sample }}$ and $\mathrm{V}_{0 \text { Blank }}$ represent the initial velocities of samples and blank. IC50 values were obtained though Log-Probit plotting. Galanthamine $\mathrm{HBr}$ was used as positive control.
Enzyme kinetic measurements were carried out to elucidate the inhibitory mechanisms. Enzyme assay experiments were performed in the presence of different sets of concentrations of essential oils $(0-0.125 \% \mathrm{v} / \mathrm{v})$ and substrate (ATCI: $0.1-0.4 \mathrm{mM})$. The nature of inhibitions was determined by analysis of kinetic parameters $\left(\mathrm{K}_{\mathrm{m}}, \mathrm{V}_{\max }, \mathrm{Ki}, \mathrm{K}\right.$ 'i) calculated from Lineweaver-Burk plots, Dixon plots (Dixon, 1953) and their secondary replots (Cornish-Bowden, 1974).

\section{Free radical (DPPH) scavenging activity}

DPPH radical scavenging activity was measured as described by Velasquez et al. (2003). Briefly, $1.5 \mathrm{~mL}$ of a freshly prepared DPPH solution $(20 \mathrm{mg} / \mathrm{mL}$ in methanol) was added to $0.75 \mathrm{~mL}$ of essential oil $(0.1 \% \mathrm{v} / \mathrm{v}$ in methanol). After shaking, the mixture was incubated for $15 \mathrm{~min}$ in darkness at room temperature and then absorbance was measured at $517 \mathrm{~nm}$ against a blank (mixture without essential oil). Inhibition percentage of free DPPH radicals (I \%) was calculated following the formula:

$$
\mathrm{I}(\%)=\left(1-\mathrm{A}_{\text {Sample }} / \mathrm{A}_{\text {Blank }}\right) \times 100
$$

$\mathrm{A}_{\text {blank }}$ and $\mathrm{A}_{\text {sample }}$ are the absorbance of the blank and sample reactions. Samples exhibiting more than $50 \%$ inhibition were considered for IC50 determination. Essential oil concentration scavenging 50\% of DPPH radicals (IC50) was calculated from the plotting of inhibition percentage versus sample concentration. Ascorbic acid and gallic acid were used as positive controls.

\section{Ferric-reducing antioxidant power assay (FRAP)}

The $\mathrm{Fe}(\mathrm{III})$ to $\mathrm{Fe}(\mathrm{II})$ reducing power was evaluated as described by Hinneburg et al. (2006). Briefly, $1 \mathrm{~mL}$ of each essential oil sample $(0.1 \% \mathrm{v} / \mathrm{v}$ in methanol) was mixed with $2.5 \mathrm{~mL}$ of phosphate buffer $(0.2 \mathrm{M}, \mathrm{pH} 6.6)$ and $2.5 \mathrm{~mL}$ of potassium hexacyanoferrate ( $1 \%$ in water) solution. After $30 \mathrm{~min}$ incubation at $50{ }^{\circ} \mathrm{C}, 2.5 \mathrm{~mL}$ of trichloroacetic acid $(10 \%$ in water) was added, and the mixture centrifuged at $3000 \mathrm{rpm}$ for $10 \mathrm{~min}$. The supernatant $(2.5 \mathrm{~mL})$ was mixed with $2.5 \mathrm{~mL}$ of water and $0.5 \mathrm{~mL}$ of aqueous $\mathrm{FeCl} 3(0.1 \%)$, then absorbance was read at $700 \mathrm{~nm}$. Ascorbic acid was used to generate the calibration curve. The reducing power was expressed as mg ascorbic acid equivalent $\mathrm{g}-1$ of pure essential oil (mg AAE/g). Gallic acid was used as positive control.

\section{Gas chromatography-Mass spectrometry (GC-MS)}

Separation of samples $(0.1 \mu \mathrm{L})$ were achieved on 
a SPB-1 (E. camaldulensis, O. basilicum, L. multiflora, C. giganteus) or DB-1 (O. canum, C. citratus) capillary columns (length: $30 \mathrm{~m}$; inner diameter: $0.25 \mathrm{~mm}$; film thickness: $0.25 \mu \mathrm{m}$ ) using helium as carrier gas at a flow rate of $1 \mathrm{~mL} / \mathrm{min}$. The oven temperature was 40 ${ }^{\circ} \mathrm{C}$ to $240{ }^{\circ} \mathrm{C}$ at $2{ }^{\circ} \mathrm{C} / \mathrm{min}$ and held isothermal for 40 $\min$. The GC injector and transfer line were set at 210 ${ }^{\circ} \mathrm{C}$ and $280{ }^{\circ} \mathrm{C}$ respectively. The mass spectrometer parameters for EI (electron impact) mode were ion temperature source $220^{\circ} \mathrm{C}$, electron energy $70 \mathrm{eV}$ and detector temperature $280{ }^{\circ} \mathrm{C}$. Individual constituents were identified by their Kovat's indices referring to the compounds known from the literature data (Adams, 1995) and by comparing their mass spectra with those stored in the Wiley mass spectral database.

\section{Statistical analysis}

Assays were performed in triplicate and data presented as mean \pm standard deviation. Statistical significance of each test $(n=3)$ was evaluated with Turkey test using GraphPad Prism ${ }^{\circledR}$ software at $p$ value $<0.01$ considered as being significant. Correlations between antioxidant data were analysed through Person's correlation coefficient (Thaipong et al., 2006).

\section{Results and Discussion}

\section{Acetylcholinesterase enzyme inhibitory activity}

As summarized in Table 1, all the essential oils tested exhibited moderate $(25-50 \%)$ to strong $(>50 \%)$ inhibitory activity at the concentration of $0.01 \%(\mathrm{v} / \mathrm{v})$. The best inhibitory activities were recorded for the essential oils of Eucalyptus camaldulensis (83\%) and Ocimum canum $(72 \%)$. Their antiacetylcholinesterase activities were compared to that of galanthamine $\mathrm{HBr}$ through their IC50 values. E. camaldulensis (IC50 $18.98 \mu \mathrm{g} / \mathrm{mL}$ ) is twice more active than $O$. canum (IC50 $36.16 \mu \mathrm{g} / \mathrm{mL}$ ), both being less potent than our reference galanthamine $\mathrm{HBr}$ (IC50 $0.19 \mu \mathrm{g} / \mathrm{mL}$ ).

The in vitro anticholinesterase activity of $E$. camaldulensis and $O$. canum essential oil are very interesting compared to those of Salvia lavandulaefolia and Rosmarinus officinalis which demonstrated some valuable therapeutic effects with less strong in vitro bioactivity. Indeed, the essential oil of S. lavandulaefolia, suggested to be relevant in the treatment of dementia of the Alzheimer's type (Perry et al., 2000) exhibited an IC50 of $50 \mu \mathrm{g} / \mathrm{mL}$ (Savelev et al., 2003) while that of $R$. officinalis with an IC50 value of $70 \mu \mathrm{g} / \mathrm{mL}$ (Mata et al., 2007) enhanced the performance and overall quality of memory in healthy adults (Moss et al., 2003). The essential oil of S. lavandulaefolia demonstrated also significant effects on cognition (Perry et al., 2003).

\section{Inhibition mechanism}

Kinetic parameters $\left(\mathrm{K}_{\mathrm{m}}, \mathrm{V}_{\max }, \mathrm{Ki}, \mathrm{K}\right.$ 'i) recorded for $E$. camaldulensis and $O$. canum were given in Table 2 . Both essential oils decrease the maximum velocity of catalysis $\left(\mathrm{V}_{\max \text { app }}<\mathrm{V}_{\max }\right)$ as well as the affinity of substrate for the enzyme $\left(\mathrm{K}_{\mathrm{m} \text { app }}>\mathrm{K}_{\mathrm{m}}\right)$. Ki and $\mathrm{K}$ 'i values recorded were different $\left(\mathrm{Ki} \neq \mathrm{K} \mathrm{K}^{\prime} \mathrm{i}\right)$.

According to Cornish-Bowden (1974), E. camaldulensis and $O$. canum essential oils inhibit the enzyme acetylcholinesterase following a linear mixed non competitive mechanism.

\section{Antioxidant activity}

Free radicals-scavenging capacity

The DPPH test intends to measure the ability of essential oils to scavenge the stable radical 2,2diphenyl-1-picrylhydrazyl $(\mathrm{DPPH} \bullet)$ in solution by donation of hydrogen atom or electron. Essential oils exhibited weak to strong free $\mathrm{DPPH} \cdot$ scavenging activity (weak: $<25 \%$; moderate: $25-50 \%$; strong: $>50 \%)$ at the tested concentration of $0.1 \%(\mathrm{v} / \mathrm{v})$. The best free radicals scavenging activity was obtained with the essential oil of Ocimum basilicum which scavenged $96 \%$ of DPPH $\cdot$. A moderate activity (39\% inhibition) was recorded with Lippia multiflora essential oil while the other essential oils gave weak inhibitions. As shown in Table 1, the essential oil of O. basilicum (IC50 $3.82 \mu \mathrm{g} / \mathrm{mL}$ ) was six fold less active than our reference antioxidant standard gallic acid (IC50 $0.61 \mu \mathrm{g} / \mathrm{mL}$ ) while it exhibit statistically the same activity than ascorbic acid.

\section{Reducing power}

The FRAP assay was used to estimate the reducing power of essential oils resulting from their electron-donating capacity. The highest reducing capacity was recorded for the essential oil of Ocimum basilicum (531.75 mg AAE/g) followed by those of Cymbopogon giganteus (75.74 mg AAE/g) and Lippia multiflora (65.49 mg AAE/g). The reducing power of $O$. basilicum essential oil (531.75 mg AAE/g) was slightly more important than that of gallic acid (445.40 mg AAE/g) as summarized in Table 1.

A very significant correlation $(\mathrm{r}=0.96, p<0.01)$ was recorded between DPPH and FRAP assays, indicating that essential oils we tested had comparable activities in the two antioxidant methods. This is not always the case when testing the antioxidant activities of plant extracts. A significant correlation was found 
between DPPH and FRAP assays with methanol extract of guava fruit while its dichloromethane extract did not show any correlation (Thaipong et al., 2006) nor the hydrodistilled extracts of some herbs and spices (Hinneburg et al., 2006). The antioxidant activities evaluation of eleven essential oils did not mention any concordance using DPPH, photochemiluminescence and B-carotène tests (Sacchetti et al., 2005).

Taking in account the DPPH and FRAP models to evaluate the antioxidant capacity of the screened essential oils, Ocimum basilicum seems to be a promising source of natural antioxidant.

\section{Chemical composition of most active essential oils}

Essential oils of E. camaldulensis and $O$. canum exhibited the best antiacetylcholinesterase activity while $\mathrm{O}$. basilicum was the most antioxidant. The hydrodistillation yield from fresh leaves was $2 \%$, $1.5 \%$ and $0.2 \%$ respectively. Chemical composition of essential oils is summarized in Table 3 . The most abundant components in E. camaldulensis essential oil were 1,8-cineole $(33.9 \%), \alpha$-pinene $(12.5 \%)$, $p$-cymene $(12.3 \%)$ and limonene $(11.5 \%)$. Smaller amount of viridiflorol, spatulenol, bicyclogermacrene, $\alpha$-terpineol, terpin-1-en-4-ol and $\alpha$-phellandrene were also detected. Composition pattern recorded for the essential oils of $O$. canum was 1,8 -cineole $(59.9 \%)$, camphor $(8.1 \%), \beta$-pinene $(5.4 \%), \alpha$-terpineol $(4.6 \%)$ and $\alpha$-pinene $(4.5 \%)$ while that of $O$. basilicum contain mainly linalool $(48.7 \%)$, eugenol $(27.5 \%)$, trans- $\alpha$ bergamotene $(5.4 \%)$ and $\delta$-cadinol $(3.4 \%)$. Major components encountered in essential oils of $O$. canum and $O$. basilicum are remarkably variable in occurrence and concentration. Several chemotypes have been reported (Chalchat et al., 1999; Ekundayo et al., 1989; Grayer et al., 1996; Keita et al., 2000; Martins et al., 1999; Yayi et al., 2001). Fewer chemotypes have been reported for Eucalyptus camaldulensis essential oil (Dagne et al., 2000; Samate et al., 1998).

Since medicinal or pesticidal activity of essential oils depends obviously on their chemical profile, reports on their biological properties have little value if their chemotype have not been determined (Grayer et al., 1996). Hence, depending on their major constituents as stated by Grayer's chemotype classification system (Grayer et al., 1996), the essential oil of $O$. basilicum could be related to the linalooleugenol chemotype and those of $O$. canum and $E$. camaldulensis to the 1,8-cineole chemotype.

Table 1. Antiacetylcholinesterase and antioxidant activities of essential oils.

\begin{tabular}{|c|c|c|c|c|c|}
\hline \multirow{2}{*}{ Essential oils } & \multicolumn{2}{|c|}{ Antiacetylcholinesterase activity } & \multicolumn{2}{|c|}{ Radical DPPH scavenging activity } & \multirow{2}{*}{$\frac{\text { Reducing power }}{\text { (mg AAE/g) }}$} \\
\hline & Inhibition $(\%)$ & $\operatorname{IC50}(\mu \mathrm{g} / \mathrm{ml})$ & Inhibition $(\%)$ & $\operatorname{IC50}(\mu \mathrm{g} / \mathrm{ml})$ & \\
\hline Cymbopogon citratus & $30.98 \pm 0.97^{\mathrm{a}}$ & n.d & $7.48 \pm 0.25^{\mathrm{a}}$ & n.d & $47.57 \pm 2.56^{\mathrm{a}}$ \\
\hline Cymbopogon giganteus & $36.20 \pm 2.20^{\mathrm{a}}$ & n.d & $18.76 \pm 0.13^{\mathrm{b}}$ & n.d & $75.74 \pm 2.14^{b}$ \\
\hline Eucalyptus camaldulensis & $83.41 \pm 1.33^{b}$ & $18.98 \pm 0.74^{\mathrm{a}}$ & $3.68 \pm 0.25^{\mathrm{a}}$ & n.d & $6.47 \pm 1.34^{\mathrm{c}}$ \\
\hline Ocimum canum & $72.13 \pm 0.49^{\mathrm{c}}$ & $36.16 \pm 1.48^{b}$ & $5.20 \pm 0.51^{\mathrm{a}}$ & n.d & $9.35 \pm 0.93^{\mathrm{c}}$ \\
\hline Ocimun basilicum & $32.43 \pm 2.49^{\mathrm{a}}$ & n.d & $95.70 \pm 0.20^{\mathrm{c}}$ & $3.82 \pm 0.98^{\mathrm{a}}$ & $531.75 \pm 10.31^{\mathrm{d}}$ \\
\hline Lippia multiflora & $43.08 \pm 2.72^{\mathrm{d}}$ & n.d & $39.29 \pm 1.65^{\mathrm{d}}$ & n.d & $65.49 \pm 1.37^{\mathrm{b}}$ \\
\hline Galanthamine $\mathrm{HBr}(10 \mu \mathrm{g} / \mathrm{ml})$ & $98.28 \pm 1.20^{\mathrm{e}}$ & $0.19 \pm 0.02^{\mathrm{c}}$ & n.d & n.d & n.d \\
\hline Ascorbic acid $(3 \mu \mathrm{g} / \mathrm{ml})$ & n.d & n.d & $86.16 \pm 0,32^{\mathrm{c}}$ & $1.80 \pm 0,43^{\mathrm{a}}$ & n.d \\
\hline Gallic acid $(1.5 \mu \mathrm{g} / \mathrm{ml})$ & n.d & n.d & $91,40 \pm 0,37^{\mathrm{c}}$ & $0.61 \pm 0.01^{\mathrm{b}}$ & $445.40 \pm 1.70^{\mathrm{e}}$ \\
\hline
\end{tabular}

Values were expressed as mean $\pm \mathrm{SD}$ of three replicates; n.d.: Not determined. Antiacetylcholinesterase activity was evaluated at the final concentration of $0.01 \%(\mathrm{v} / \mathrm{v})$ essential oil. Antioxidant activities were evaluated at the final concentration of $0.1 \%$ $(\mathrm{v} / \mathrm{v})$ essential oil. IC50 expressed the concentration of essential oil $(\mu \mathrm{g} / \mathrm{ml})$ inhibiting $50 \%$ of acetylcholinesterase activity or scavenging $50 \%$ of free DPPH. Reducing power was given as $\mathrm{mg}$ Ascorbic Acid Equivalent/g of essential oil (mg AAE/g). Data from the same column, marked with the same letter doesn't shown statistical differences by Turkey test $(p<0.01)$

Table 2. Acetylcholinesterase inhibition parameters.

\begin{tabular}{cccc}
\hline Essential oils & $\mathrm{Km}, \mathrm{Vm}$ & $\mathrm{Ki}(\mu \mathrm{g} / \mathrm{mL})$ & $\mathrm{K}{ }^{\prime} \mathrm{i}(\mu \mathrm{g} / \mathrm{mL})$ \\
\hline \multirow{2}{*}{ Eucalyptus camaldulensis } & $\mathrm{K}_{\mathrm{m} \text { app }}>\mathrm{K}_{\mathrm{m}}$ & $8,52 \pm 0,90 \mathrm{a}$ & $39,56 \pm 2,60 \mathrm{~b}$ \\
& $\mathrm{~V}_{\text {m app }}<\mathrm{V}_{\mathrm{m}}$ & & \\
Ocimum canum & $\mathrm{K}_{\mathrm{m} \text { ap }} \mathrm{p}>\mathrm{K}_{\mathrm{m}}$ \\
& $\mathrm{V}_{\mathrm{m} \text { app }}<\mathrm{V}_{\mathrm{m}}$ & $7,71 \pm 0,06 \mathrm{a}$ & $48,46 \pm 0,66 \mathrm{~b}$ \\
\hline
\end{tabular}

Values were expressed as mean $\pm \mathrm{SD}$ of three replicates; Michaelis constant $\left(\mathrm{K}_{\mathrm{m}}\right)$, apparent Michaelis constant $\left(\mathrm{K}_{\mathrm{m} \text { app }}\right)$, maximum velocity $\left(\mathrm{V}_{\max }\right)$, apparent maximum velocity $\left(\mathrm{V}_{\max }{ }_{\text {app }}\right)$. Dissociation constants of the complex [Enzyme]-Inhibitor (Ki) and [Substrate-Enzyme]-Inhibitor (K'i). Data from the same line, marked with the same letter doesn't shown statistical differences by Turkey test $(p<0.01)$ 


\section{Bioactivity related to chemical composition}

Major compounds identified in essential oils (Table 3) were 1,8-cineole (33.9\%), $\alpha$-pinene $(12.5 \%)$, $p$-cymene $(12.3 \%)$, limonene $(11.5 \%)$ for E. camaldulensis; 1,8-cineole $(59.9 \%)$, camphor $(8.1 \%)$ for $O$. canum and linalool (48.7\%), eugenol (27.5\%) for O. basilicum. Except eugenol, all these compounds have been previously found to inhibit individually AChE; 1,8-cineole being the most potent followed by $\alpha$-pinene, camphor and linalool (Savelev et al., 2003; Miyazawa et al., 1997). Mixtures of 1,8cineole/ $\alpha$-pinene demonstrated a minor synergistic impact while 1,8-cineole/camphor combinations antagonize the antiacetylcholinesterase activity (Savelev et al., 2003). Individual inhibitory activity of 1,8 cineole and $\alpha$-pinene as well as the antagonism impact of 1,8-cineole/camphor mixture may justify the anticholinesterase potency of $E$. camaldulensis essential oil compared to $O$. canum.

The antioxidant capacity of $O$. basilicum essential oil could be mainly related to the occurrence of eugenol as assessed by Politeo et al. (2007).

\section{Conclusion}

The results of this work point out that all the essential oils tested possess anticholinesterase activity. Meanwhile, the most potent inhibitors were $E$. camaldulensis followed by $O$. canum essential oils. Both essential oils inhibit AChE though a linear mixed non competitive mechanism. On another hand,

Table 3. Composition of most active essential oils.

\begin{tabular}{|c|c|c|c|}
\hline \multirow{2}{*}{ Compounds (KI) } & \multicolumn{3}{|c|}{ Composition (\%) } \\
\hline & E. camaldulensis & O. canum & O. basilicum \\
\hline Monoterpene hydrocarbons & $41.6^{\mathrm{c}}$ & $15.5^{\mathrm{c}}$ & $2.4^{\mathrm{c}}$ \\
\hline$\alpha$-pinene $\left(934^{\mathrm{a}}, 933^{\mathrm{b}}\right)$ & 12.5 & 4.5 & - \\
\hline camphene $\left(949^{a}\right)$ & n.i & 1.1 & n.i \\
\hline ß-pinene $\left(973^{\mathrm{a}}, 969^{\mathrm{b}}\right)$ & - & 5.8 & - \\
\hline myrcene $\left(990^{\mathrm{a}}, 986^{\mathrm{b}}\right)$ & - & 1.4 & - \\
\hline$\alpha$-phellandrene $\left(993^{\mathrm{b}}\right)$ & 3.8 & n.i & n.i \\
\hline$p$-cymene $\left(1010^{\mathrm{b}}\right)$ & 12.3 & n.i & n.i \\
\hline limonene $\left(1026^{\mathrm{a}}, 1022^{\mathrm{b}}\right)$ & 11.5 & - & - \\
\hline trans- $\beta$-ocimene $\left(1048^{\mathrm{b}}\right)$ & n.i & n.i & 1.2 \\
\hline Oxygenated monoterpenes & $41.8^{c}$ & $78.1^{\mathrm{c}}$ & $82.5^{\mathrm{c}}$ \\
\hline 1,8 -cineole $\left(1026^{\mathrm{a}}, 1018^{\mathrm{b}}\right)$ & 33.9 & 59.9 & 1.6 \\
\hline linalool $\left(1098^{\mathrm{a}}, 1103^{\mathrm{b}}\right)$ & - & 1.2 & 48.7 \\
\hline camphor $\left(1124^{a}\right)$ & n.i & 8.1 & 1.2 \\
\hline terpin-1-en-4-ol $\left(1172^{\mathrm{a}}, 1162^{\mathrm{b}}\right)$ & 1.7 & 1.7 & - \\
\hline$\alpha$-terpineol $\left(1182^{\mathrm{a}}, 1172^{\mathrm{b}}\right)$ & 2.6 & 4.6 & - \\
\hline bornyl acetate $\left(1276^{\mathrm{a}}, 1271^{\mathrm{b}}\right)$ & n.i & 1.4 & 1.1 \\
\hline eugenol $\left(1337^{\mathrm{b}}\right)$ & n.i & n.i & 27.5 \\
\hline Sesquiterpenes hydrocarbons & $2.9^{\mathrm{c}}$ & $5.2^{\mathrm{c}}$ & $9.6^{\mathrm{c}}$ \\
\hline ß-caryophyllene $\left(1421^{\mathrm{a}}, 1398^{\mathrm{b}}\right)$ & - & 1.7 & n.i \\
\hline trans- $\alpha$-bergamotene $\left(1433^{\mathrm{a}}, 1427^{\mathrm{b}}\right)$ & n.i & 1 & 5.4 \\
\hline$\alpha$-farnesene $\left(1483^{\mathrm{a}}\right)$ & n.i & 2 & n.i \\
\hline bicyclogermacrene $\left(1481^{b}\right)$ & 1.9 & n.i & - \\
\hline$\gamma$-cadinene $\left(1500^{\mathrm{b}}\right)$ & n.i & n.i & 1.1 \\
\hline Oxygenated sesquiterpenes & $7^{\mathrm{c}}$ & Not determined ${ }^{c}$ & $4.3^{c}$ \\
\hline spatulenol $\left(1549^{\mathrm{b}}\right)$ & 2.5 & n.i & - \\
\hline viridiflorol $\left(1558^{\mathrm{b}}\right)$ & 1.8 & n.i & n.i \\
\hline globulol $\left(1563^{\mathrm{b}}\right)$ & 1 & n.i & n.i \\
\hline$\delta$-cadinol $\left(1622^{\mathrm{b}}\right)$ & n.i & n.i & 3.4 \\
\hline
\end{tabular}

Compounds representing less than $1 \%$ in all essential oils were not listed; (-) compounds identified at a concentration less than $1 \%$; n.i. Non identified compounds. ${ }^{\mathrm{a}, \mathrm{b}}$ Kovat's indices (KI) obtained with respect on DB-1 and SPB-1 columns; ${ }^{\text {cT}}$ Total percentage of each class of monoterpene and sesquiterpene identified. 
E. camaldulensis, $O$. canum and Cympobogon citratus essential oils show very weak antioxidant activities while the essential oil of $O$. basilicum exhibited promising antioxidant abilities. Through GC-MS analyses, we related $E$. camaldulensis and $O$. canum to the 1,8-cineole chemotype and $O$. basilicum to the linalool-eugenol one.

\section{Acknowledments}

This research was financially supported by the International Foundation for Science (Sweden) through the project F3979-1 granted to the main author. We are also grateful to the International Atomic Energy Agency (Vienna) for providing the basic equipments of the laboratory through the Technical Cooperation Project BKF 5002.

\section{References}

Adams RP 1995. Identification of essential oil components by gas chromatography / mass spectroscopy. Allured Publishing Corporation: Illinois, USA.

Bierer LM, Haroutunian V, Gabriel S, Knott PJ, Carlin LS, Purohit DP, Perl DP, Schmeidler J, Kanof P, Davis KL 1995. Neurochemical correlates of dementia severity in Alzheimer disease: relative importance of the cholinergic deficits. J Neurochem 64: 749-760.

Chalchat JC, Garry RP. Sidibe L, Harama M 1999. Aromatic plants of Mali (II): Chemical composition of essential oil of Ocimum canum sims. J Essent Oil Res 11: 473476.

Cornish-Bowden A 1974. A simple graphical method for determining the inhibition constants of mixed, uncompetitive and non competitive inhibitors. Biochem J 137: 143-144.

Dagne E, Bisrat D, Alemayehu M, Worku T 2000. Essential oils of twelve Eucalyptus species from Ethiopia. $J$ Essent Oil Res 12: 467-470.

Dixon M 1953. The determination of enzyme inhibitor constants. Biochem J 55: 170-171.

Ekundayo O, Laakso I, Hitunen R 1989. Constituents of the volatile oil from the leaves of Ocimum canum Sims. Flavour Frag $J$ 4: 17-18.

Ellman GL, Courtney KD, Andres V Jr, Featherstone RM 1961. A new rapid colorimetric determination of acetylcholinesterase activity. Biochem Pharmacol 7: 88-95.

Enz A, Amstutz R, Boddeke H, Gmelin G, Malonowski J 1993. Brain selective inhibition of acetylcholinesterase: a novel approach to therapy for Alzheimer's disease. In Cholinergic Function and Dysfunction, Progress in Brain Research, Cuello AC (ed). Elsevier Science Publisher: Amsterdam; 431-445.

Gibson GE, Huang H-M 2005. Oxidative stress in Alzheimer's disease. Neurobiol Aging 26: 575-578.

Grayer RJ, Kite GC, Goldstone FJ, Bryan SE, Paton A, Putievsky E 1996. Intraspecific taxonomy and essential oil chemotypes in sweet basil, Ocimum basilicum. Phytochemistry 43: 1033-1039.

Hinneburg I, Dorman HJD, Hiltunen R 2006. Antioxidant activities of extracts from selected culinary herbs and spices. Food Chem 97: 122-129.

Keita SM, Vincent C, Schmit JP, Belanger A 2000. Essential oil composition of Ocimum basilicum L., O. gratissimum L. and $O$. suave L. in the Republic of Guinea. Flavour Frag J 15: 339-341.

Martins AP, Salgueiro L, Vila R, Tomi F, Canigueral S, Casanova J, Proenca-da-Cunha A, Adzet T 1999. Composition of the essential oil of Ocimum canum, O. gratissimum and O. minimum. Planta Med 65: 187189.

Mata AT, Proença C, Ferreira AR, Serralheiro MLM, Nogueira JMF, Araújo MEM 2007. Antioxidant and antiacetylcholinesterase activities of five plants used as Portuguese food spices. Food Chem 103: 778-786.

Miyazawa M, Watanabe H, Kameoka H 1997. Inhibition of acetylcholinesterase activity by monoterpenoids with a p-methane skeleton. J Agric Food Chem 45: 677679.

Moss M, Cook J, Duckett P 2003. Aromas of Rosemary and lavender essential oils differently affect cognition and mood in healthy adults. Int J Neurosci 113: 15-38.

Nacoulma OG. 1996 Plantes médicinales et pratiques médicales traditionnelles au Burkina Faso: Cas du plateau central. Tome 2. Ph.D. thesis, University of Ouagadougou.

Perry N, Howes MJ, Houghton P, Perry E 2000. Why sage may be a wise remedy: effects of Salvia on the nervous system. In Sage The genus Salvia, Kintzios (ed).Harwood Academic Publishers: The Netherlands; 207-232.

Perry NL, Bollen C, Perry EK, Ballard C 2003. Salvia for dementia therapy: review of pharmacological activity and pilot tolerability clinical trial. Pharmacol Biochem Be 75: 651-659.

Politeo O, Jukic M, Milos M 2007. Chemical composition and antioxidant capacity of free volatile aglycones from basil (Ocimum basilicum L.) compared with its essential oil. Food Chem 101: 379-385.

Sacchetti G, Maietti S, Muzzoli M, Scaglianti M, Manfredini S, Radice M, Bruni R 2005. Comparative evaluation of 11 essential oils of different origin as functional antioxidants, antiradicals and antimicrobials in foods. Food Chem 91: 621-632.

Samate D, Nacro M, Menut C, Lamaty G, Bessiere JM 1998. Aromatic plants of West Africa. VII. Chemical composition of the essential oils of two Eucalyptus species (Myrtaceae) from Burkina Faso: Eucalyptus alba Muell. and Eucalyptus camaldulensis Dehnardt. 
J Essent Oil Res 10: 321-324.

Savelev S, Okello E, Perry NSL, Wilkins RM, Perry EK 2003. Synergistic and antagonistic interactions of antiacetylcholinesterase terpenoids in Salvia lavandulaefolia essential oil. Pharmacol Biochem Be 75: 661-668.

Stuchbury G, Munch G 2005. Alzheimer's associated inflammation, potential drug targets and future therapies. J Neural Transm 112: 429-453.

Thaipong K, Boonprakob U, Crosby K, Cisneros-Zevallos L, Byrne DH 2006. Comparison of ABTS, DPPH, FRAP and ORAC assays for estimating antioxidant activity from guava fruit extracts. J Food Compost Anal 19: 669-675.

Velasquez E, Tournier HA, Mordujovichole BP, Saadevra G, Scinella GR 2003. Antioxidant activity of Paraguayan plants extracts. Fitoterapia 74: 91-97.

Vina J, Lloret A, Orti R, Alonso D 2004. Molecular bases of the treatment of Alzheimer's disease with antioxidants: Prevention of oxidative stress. Mol Aspects Med 25: 117-123.

Yayi E, Moudachirou M, Chalchat JC 2001. Chemotyping of three Ocimum species from Benin: O. basilicum, $O$. canum, O. gratissimum. J Essent Oil Res 13: 13-17.

\section{*Correspondence}

\section{Martin Kiendrebeogo}

Laboratoire de Biochimie \& Chimie Appl iquées, UFR/SVT, Université de Ouagadougou, 09 BP 848 Ouagadougou 09, Burkina Faso

martin.k@univ-ouaga.bf

Tel. +22670608590

Fax: +22650307242 